\title{
VISTOS DESDE AFUERA
}

\section{Dos libros de Armando Donoso}

(De Nosotros de Buenos Aires)

19. E su último viaje a España, Armando Donoso ha traido dos libros, hechos con ensayos que vieron la luz en diarios y revistas de América, entre éstas Nosofros.

La ofra América, según su autor lo explica. es la opuesta a la que vió Baroja cuando Tormuló su despiadado epiteto, a través de su escasa información y de los niños bien que, calzando puntos de literatos, pasan por Madrid, de vez en cuando, pagan banquetes en el Ritz o el Palace, se hacen presentar al Rey para admirar de cerca el corte de su saco o el color de sus calcetines, hacen un soneto cojo al Dia de la Raza y terminan por irse a Paris, donde generalmente llegan diciendo pestes de ces sales espagnols; para quedar bien, a la vez, con los palrioteros franceses, que escriben articulos para los diarios de América, hablándonos de cosas tan interesantes como de las queridas de Luis XIV. los procesos del año en la Corte de Justicia o las heroicidades del último apache, y se dan el titulo de obreros del acercamiento espiritual latino-americano.

En La ofra América, titulo que es un felicísimo hallazgo de Donoso, tienen cabida ocho ensayos, dedicados a Gabriela Mistral. Arturo Cancela. Pedro Henriquez Ureña, Rafael Barret, Karez-I-Roshan, Eduardo Barrios, José Toribio Medina y Totila Albert.

Hay, en efecto. otra América, una grande, desconocida y ca- 
lumniada América, que no sólo los europeos no ven, sino que también muchos hispano-americanos (pues nos estamos refiriendo, al decir América, como se habrá comprendido, a HispanoAmérica), afectan ignorar o realmente desconocen por falta de sentido observador, de sensibilidad o simplemente por obstinación rastacuera.

Diez Canedo, que prologa La otra América, apunta con su perspicacia de fino critico. las razones en que se lunda para. él también, creer en esa ofra América cuyo crecimiento rítmico. ordenado, revelador. se muestra vigorosamente desde Méjico a Santiago y Buenos Aires, desde Montevideo a Bogotá, aunque. como es natural y ya lo hemos señalado, con mayor empuje en la periferia.

Tal vez no todos los ocho nombres incluidos por Donoso en La otra América, tengan el carácter representativo de que éste parece investirlos. On est toujours un peu le caméléon de ses amitiés, decía Barbey d'Aurevilly, a propósito de las poesias de Charles Monselet y la frase, sin malicia, puede tambiẻn ser aplicada a un crítico. Diez Canedo ya excluye dos: Barret y Totila Albert. Somos amigos del segundo y a despecho de la frase de Barbey citada más arriba, podemos afirmar que está en lo cierto el critico español respecto al joven escultor maestro de Las mujeres de la montaña.

$\mathrm{Y}$ en cuanto a Barret. tampoco disentimos... Pero necesitamos explicarnos un poco. El poder de asimilación de HispanoAmérica sobre todos los hombres que llegan a pisarla y habitarla con continuidad e intensamente, es formidable, y se manifiesta. como es lógico, en forma más completa y rápida sobre los hombres de su misma lengua. Pero donde ese poder de asimilación se embota. es cuando debe actuar sobre el político - el sociólogo, es decir, sobre el hombre que ha encasillado sus ideas y sus sentimientos. Un politico es siempre un sectario. Sobre fodo cuando su credo es extremista, bien sea hacia la derecha o hacia la izquierda. Esto. aunque parezca contradictorio con la definición de político. Lo que comenzó siendo una cosa, después terminó siendo la opuesta y siempre guardó 
el mismo nombre, tal vez por olvido. El talento de los gobernantes está en saber ceder a tiempo, decia el cardenal de Retz. que a pesar de su sotana roja, fué un gran politico en la verdadera acepción del vocablo. El dia en que esta sentencia fué olvidada. la politica dejó de ser politica para ser sectarismo.

pues bien, Barret, a pesar de haberse formado entre nosotros. nunca se asimiló a los hispano-americanos, porque él veía todo desde su tronera politico-social. Llegó a América ya polifico y polifico se fué, el pobre, a pesar de su talento y de su gran corazón. En él no está la otra América, aun cuando sea tema de sus escritos una inquietud bien nuestra, porque está sentida con otra sensibilidad y sobre todo con el preconcepto de su posición ante esa inquietud.

Conocemos un español inteligentisimo, abogado y periodista. que vive entre nosotros hace cuarenta años. Hace quince, cuando le tratamos por primera vez, le oiamos hablar espantados de que a pesar de sus veinticinco años de Buenos Aires este hombre sintiera y pensara con una sensibilidad y un cerebro tan alejado del nuestro. Habia llegado aqui a raiz de no sé qué expulsiones de republicanos y seguia, después de veinticinco años, erre que erre sobre el mismo pollino. No es del caso ahora, poner de manifiesto cuáles eran las ideas de nuestro abogado... Le perdimos de vista. Hace dos años nos invitan a una peña literaria de españoles, y apenas llegamos. lo primero que Dios nos deparó fué al señor que habiamos conocido trece años atrảs, siempre encastillado en sus mismos sofismas. $Y$ por si no era bastante. apenas nos vió. indirectamente aludió a las luchas sostenidas años atrás, que lo fueron entre su intransigencia y nuestro espiritu amplio y acogedor, verdadero espiritu de Hispano-América. circunstancia que, no conocida de los presentes. les llenó de perplejidad por no saber a dónde iba el disertante.

Este ejemplo es uno. Podriamos citar mil. Por eso hemos aprobado la exclusión hecha por Diez Canedo que supo ver inmediatamente en el caso Barret, como en el caso Totila, aunque este último sea de otra indole y de más fácil percepción. $\mathrm{Y}$ de la indole del de Totila Albert puede ser algún otro 
más que citariamos. con intentos de exclusión también. Pero como, de hacerlo, tendriamos que actuar con espiritu dogmático y sectario, que no es precisamente el nuestro. preferimos abstenernos.

El autor y su prologuista han partido de la base de la aparición del humorismo en nuestras letras para fundar su opinión sobre la existencia de una nueva América. inadura para las grandes empresas del espiritu, bien que ambos la relacionen después con otros elementos en más acertada visión de conjunto.

No damos a esa aparición la trascendencia especial con que muchos han querido señalarla. El humorismo no es nuevo en nuestro medio. Ya el Martin Fierro encierra no pocas dosis de la divina sal. En cada paisano. bien visto, hay un tesoro de humorismo que explotar. Nuestros escritores no sabian verlo porque estaban ocupados en contar los entretenimientos de las princesas y las infantas o en inventar dolientes querellas de amores imaginarios. Cuando alguien como Hernández miró al paisano o como Wilde al pueblerino (en quien es menor ciertamente el porcentaje de humour). con ojos abiertos, apareció el humorismo y sin embargo no estaba entonces maduro nuestro medio para poder hablar de personalidad literaria; pero las bases estaban echadas.

Una golondrina no hace verano, dice el refranero popular. aun cuando Diez Canedo afirme que la rara avis del humorista de Donoso marca. despojada de ela expresión de su cuño usuals. una estación, un periodo, un punto de partida o de definición.

Lo que marca todo eso es el conjunto de apariciones. su duración y regularidad. Paralelamente, simultáneamente, dejando a un lado la poesia que la infancia del arte, aparece en la Hispano-América de hace poco y de ahora. en forma regular y continua, la novela, el ensayo, la critica. Reyles, Barrios, Lynch, Salaverri. Prado, Gálvez, Zuviria, Loveira y tantos otros en el más dificil de los géneros (convenimos en darle esta denominación. por darle alguna: pero convencidos de su vacuidad: ya hemos dicho nuestra opinión acerca de las categorias literarias como las llama Brenes Mesén). Vasconcelos. Caso. Alfonso 
Reyes, Alvarez, Rodó, Sanin Cano, Gerchunofl, recorriendo toda la gama de los ensayistas y sin citar a muchos más: Donoso, Zum Felde. Giusti. Noé. Melián Lafinur. Henriquez Ureña, Brenes Mesén como críticos y reconozco que no están todos.

La crílica. precisamente, que se ejercita a posferiori. pero que también tiene sus medios de caracterizarse. la critica de visión hispano americana, ha marcado y está marcando ese bullir de ideas y de sentimientos que revela la activa vida de HispanoAmérica.

Para guardar más el espiritu de raza, hasta en sus vicios de forma y de fondo. nuestra literatura es nuestra y por este sentido de propiedad ya inalienable, usufructuaria, hasta hace poco sólo propiedad treintenaria, si se nos permiten los términos legistas, nuestra literatura revela entrar en su periodo de verdadera personalidad.

América es. entonces, la otra América, la que ignoran por rutina o por desdén incomprensibles, hombres como Pio Baroja. que buscan inútilmente en un ideario nihilista, oriental y judaizante, él tan enemigo de los hijos de Sem, la levadura que haga fermentar de nuevo en la conciencia hispana el ansia de más grandes empresas, sin reparar que aqui, en esta otra América. que no es hija. sino hermana, se está realizando el milagro de una nueva Grecia, de la cual, con el tiempo, y ya se empieza. tendrá que aprender el mundo los ideales que lo salvarán.

Armando Donoso, que tiene un profundo sentido de la medida y a quien su gran bagaje intelectual capacita para largas vistas que sean como sintesis de momento, ha sabido aprovechar bien su viaje dejando allá un libro por el cual, quienes quieran. podrán aprender a conocernos, aunque sea imperfectamente. Despertar la curiosidad yo es mucho.

$\mathrm{Y}$ no sólo nos conocerán por los hombres de Hispano-América que presenta Donoso (¿por qué en vez de Karez-I-Roshan. no incluyó su magnifico estudio sobre Prado en La otra América, en el cual aparece de manifiesto todo el alto valor del 
padre de Un juez rural?). sino por Donoso mismo, con el libro que nos viene ocupando y Dostoievski.

Tenemos que reprocharle a Donosó un vicio del que ya se está curando $y$ en el que incurre, sin embargo, al querer enrostrárselo-y pecando dos veces-a Pedro Henriquez Ureña: el abuso de la erudición.

Nuestros criticos han padecido casi siempre del rastacuerismo de la erudición. Asi como los nuevos ricos cambian de auto cuatro veces por dia. llevan fodas sus joyas de la mañana a la noche y se hacen volcar una sopera encima por el gusto de lucir dos tocados en la misma noche. apenas alguien se siente por nuestros pagos un Sainte Beuve en miniatura. nos aplasta a citas y nombres. Ya hemos dicho que los muebles americanos y el virus alemán tienen la culpa de tales excesos.

Thibaudet-y perdónesenos este ligero pecado de cita-ha dicho: -La critique créatrice commence où l'erudition finits. El olvido de esta gran verdad. tal vez sea la causa de la castración de muchos de nuestros críticos.

La erudición agosta el poder intuitivo que debe ayudar al crítico en el buceo, en la punción del material operatorio.

Es interesante saber, para el que lo ignora, cuánto han dicho a propósito de la obra de Juan o Pedro. los señores X. Y. Z; pero es más interesante saber qué ha visto $H$, independientemente de aquellos señores, en la obra de Juan o Pedro. Estamos lejos de la herejia de proscribir al crítico la lectura, que viene a ser el entrenamiento de su facultad crítica. prohibición equivalente a producirle la atonía. Un poco de gimnasia razonada. mantiene elásticos los músculos. El exceso produce el relajamiento. tan perjudicial. o más. que la atonia.

Diez Canedo al señalar como sintomático el pase en la crífica hispano-americana del elogio o la censura al análisis, la selección y la ideología, olvidó fijar que también el pase del empacho bibliográfico. de la manía erudita a la sencillez expositiva y al juicio claro, sintético y propio, marca el hallazgo de la senda clara, por nuestros criticos.

Hecho el reproche, con el mismo espiritu de justicia y sin- 
ceridad. digamos que la tarea de Armando Donoso ha tenido en las letras hispano-americanas, un mérito imponderable. En nuestra vida afiebrada e inquieta, no todos disponen de largas horas que dedicar a la lectura. Si otro, con clara inteligencia y fino es. piritu toma a su cargo compendiar y divulgar el saber esparcido en las obras que pasan ante los ojos desencantados como una ilusión, bienvenido ese otro.

Donoso emprendió hace tiempo $\mathrm{y}$ ha venido continuando después, con verdadero espiritu evangelista, la labor de guía espiritual, realizando. como Reyes en Los dos caminos, una doble obra. Traer Europa a América y llevar América a Europa.

La otra América y Dosfoievski, son muestra reciente de la bifurcación de sus empeños.

Cuando Donoso se bate por América hay en sus criticas más humanidad, más calor de vida, que cuando trae ante nosotros escritores de Europa. Cuando trata a éstos, déjase arrastrar con más frecuencia por el peso del formidable bagaje bibliográfico que archiva su fértil memoria. Perdido en la evocación de argumentos, en el relato de opiniones, en el mar de las cilas y de las notas, su juicio se oscurece, su sensibilidad parece agostarse. De su paciente estudio sobre Dostoievski, por ejemplo. impecable de doctrina, de forma, de material, no surje como debiera la formidable figura del ruso más ruso y más humano, al mismo tiempo-esto por aquello-del siglo XIX. Falta vida y sobran libros. Escasea la intuición y abunda el razonamiento.

No hay enfermedades, sino enfermos. No hay libros, sino autores: hombres que van dejando-cuando son realmente autores-pedazos de su yo en cada página. El médico que trata la enfermedad olvidando al enfermo, incurre en igual error que el crítico que trata la obra y no al autor. Pero, el autor en la obra, como el enfermo en la enfermedad, no el autor a solas. Y para eso el médico necesita el ojo clínico y el critico la intuición. que es su ojo clínico.

Donoso. a veces, se entusiasma con el caso y se olvida del enfermo. Es lo sucedido en el ensayo de Dostoievski. Son, éstos. pequeños percances del oficio. 
Todo lo cual no obsta para que afirmemos que Donoso es una de las mentalidades más sólidas y mejor organizadas de Hispano-América y para que proclamemos nuestro respeto por quien ha sabido elevar la crítica entre nosotros a un plano superior y digno. donde están proscriplas la diatriba venenosa y el elogio hiperbólico.

E. SUÃRez calimano. 